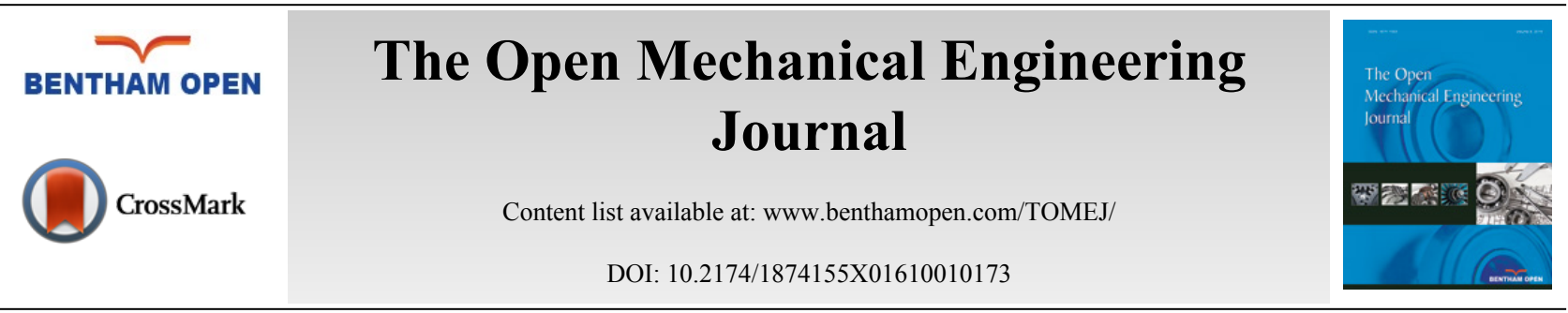

RESEARCH ARTICLE

\title{
Design Efficiency Analysis Towards Product Improvement for Eco- Friendly Using DFMA Method
}

\author{
Mohd Nizam Sudin", Ngeow Sook Chin, Shamsul Anuar Shamsudin and Mohd Asri Yusuff \\ Centre for Advanced Research on Energy, Faculty of Mechanical Engineering, Universiti Teknikal Malaysia Melaka \\ (UTeM), Malaysia
}

\begin{abstract}
This paper presents the comparative study of design efficiency of two different brands of products, performing the same function using the Design for Manufacturing and Assembly (DFMA) method. The study aims to compare the products on the relative design efficiency. The DFMA method was used as it is a well-established technique for improving the efficiency of the product leading to minimizing production costs. It also shortens product development time by reducing the number of components in a product. The study used two different brands of dry iron as a case study. The result shows that the percentage of the design efficiency of dry iron A is $8.82 \%$, whereas it is $10.34 \%$ of dry iron B. Thus, the dry iron B is much better as compared to A in term of its assembly operation and design efficiency. Therefore, the dry iron B is greener than dry iron A. Furthermore, a redesign of dry iron B was proposed and analyzed for the internal validation. The DFMA analysis result shows that the percentage of design efficiency of a new conceptual design of dry iron B increased to $18.08 \%$. The application of the DFMA method to enhance the eco-friendliness of a product has been proven to be highly useful in design work.
\end{abstract}

Keywords: Design efficiency, DFMA, Dry iron, Eco-friendly.

\section{INTRODUCTION}

\subsection{Design for Manufacture and Assembly}

Design for Manufacturing and Assembly (DFMA) is a well-established technique in product design for minimizing production costs and development time by designing products into utilizing the simplest components. DFMA is a practical design approach that allows for early consideration of manufacturing and assembly aspect of production as it is a combination of Design for Manufacturing (DFM) and Design for Assembly (DFA) methods. DFA focuses on the part consolidation for ease of assembly process. Meanwhile, DFM focuses on reducing the manufacturing cost [1]. As the basic principles of DFMA are to reduce part, it plays a key role in product development, especially in industries like automotive, in which variation in component geometry is obvious. The final aim of this approach is to give higher profit to the manufacturer [2] due to its capability to improve the design efficiency and minimizing production cost without sacrificing customers' needs [3]. The DFMA method provides a systematic procedure to determine the candidate for elimination/consolidation based on the prescribed criteria. It also facilitates the designer with design guidelines that are extracted from a good design practice for the redesign of an existing part. However, the guidelines for decreasing the part count for elimination or consolidation are limited to only by two types which are fasteners and connectors [1].

The significant benefits of DFMA are avoiding potential errors in manufacturing thus reducing remanufacturing costs of products. In addition, DFMA also provides indefinable benefits such as improving communication among the design team, thus promoting teamwork and increasing ownership among team members. The activities within DFMA

\footnotetext{
* Address correspondence to this author at the Faculty of Mechanical Engineering, Universiti Teknikal Malaysia Melaka (UTeM)76100 Durain Tunggal Melaka Malaysia; Tel: +606-234 6806; Fax:606-234 6884; E-mail: nizamsudin@utem.edu.my
} 
framework brings manufacturing personnel into the early stage of the design cycle and allows for the knowledge integration that does not happen in the traditional design approaches. DFMA considerations lead to simplification and standardization of design and manufacturing processes. It also facilitates the integration of function and form and optimizes the workflow. There are many reported examples of the application of DFMA for the design improvement from the production point of view. Prakash et al. [4] redesigned a fluid flow control valve to obtain an optimum design solution for an existing product through intensive use of DFMA throughout the product development phase. Later, they employed a rapid-prototyping process to develop a prototype for testing and validation of the new design of a valve. An optimum design, low cost and good quality with quick product delivery of the valve was achieved through the DFMA approach. In another report, the cost saving of $1.8 \%$ in the subsystem and $0.7 \%$ of the entire diesel engine were attained with the application of the DFMA method [5].

Sula and Bâlc [6] presented results of the successful validation process of a redesigned metering pump using the DFMA method. The redesign process was performed by conducting DFA analysis on the metering pump. The validation of the newly developed design strategies was conducted using a test bench. The results showed that the improvements not only shortens the assembly process, but it also streamlined the product shapes. The DFMA technique has been utilized intensively in industry for many years in order to increase the quality, decrease the cost and shorten the cycle time of a product. Another article discusses the detail application of this method in improving a pneumatic piston design as the design efficiency of the product increased significantly from $25.9 \%$ to $67.45 \%$ [7]. Even though the DFMA method was not purposely designed for supporting eco-design but its impact for environmental conscious is vital.

\subsection{Design for Sustainability}

Design for sustainability or eco-design is the systematic consideration about the performances of products being designed with respect to environmental, health, and safety in its life cycle phase [8]. There are many eco-design tools available including design guidelines, checklist methods, Life Cycle Analysis (LCA), Quality Function Deployment for Environment (QFDE), Environmental Effect Analysis (EEA), Eco-Value Analysis (Eco-VA) and Theory of Inventive Problem Solving (TRIZ). However, all of these methods attend to the environmental issue at the different stages of the product's life cycle and they require a massive input data for analysis. Recently, manufacturing organizations recognized sustainability as a value added to their survival in the competitive market. This situation has created pressure to design engineers to search for an appropriate approach in creating environmental-friendly products. In response to this demand, Suresh et al. [9] proposed an integration of Design for Environment (DFE) and DFMA as a new methodology as an environmentally-conscious design approach. Thus, to remain competitive in the market, it is necessary for a company to assess the eco-design status of their product as compared to their competitors. According to Gheorghe and Ishii [10], it is possible to focus on a specific stage of the life cycle, such that the environmental impact is minimized at that stage as well as emphasizing the entire life of the product. Thus, the application design efficiency as eco-indicator is possible as it relates to the number of components. In production point of view, the number of component of a product is directly reflected in the eco-design status of a product [11]. The sustainability of product before and after improvement has been made with the aid of DFMA approach was compared to investigate the environmental impact. The result of the study has proven that the product after improvement possesses minimal environmental impact. Thus the integration of DFE and DFMA is beneficial to improve the sustainability of the product [11]. The aforementioned study strengthens the applicability of DFMA for eco-design assessment. Therefore, this research attempts to assess the eco-friendly of a consumer product by measuring its design efficiency with the application of DFMA method.

\section{METHODOLOGY}

\subsection{Selection of Product for the Case Study}

In consideration of the research objectives, two brands of electric dry iron that are called dry iron A (produced by a reputable company) as in Fig. (1) and dry iron B (produced by a non-reputable company) as in Fig. (2) were selected as a case study. The dry irons were selected due to their availability, usage and significant contributions to the total household energy consumption. Since the research aims to compare these two products based on the design efficiency, the influence of an electrical consumption of these products in the usage phase was ignored as both of them have a similar specification which is operating at $240 \mathrm{~V}$ with a maximum power of $1000 \mathrm{~W}$. These products were disassembled and the dimension of each component was measured with a vernier caliper. The detail drawing of each component was 
reproduced with the use of CATIA V5R20 solid modeling software. The design efficiency of both products was computed based on the Boothroyd Dewhurst DFMA procedure. Indirectly, the Boothroyd Dewhurst method provides a quantitative measure of the product eco-friendliness that is also called the design efficiency as it is the ratio of the theoretical average assembly time of a part of the estimated total assembly time of an actual product. Theoretically, less number of parts in a product will contribute to the higher design efficiency that indicates the eco-friendly status of a product in relative.

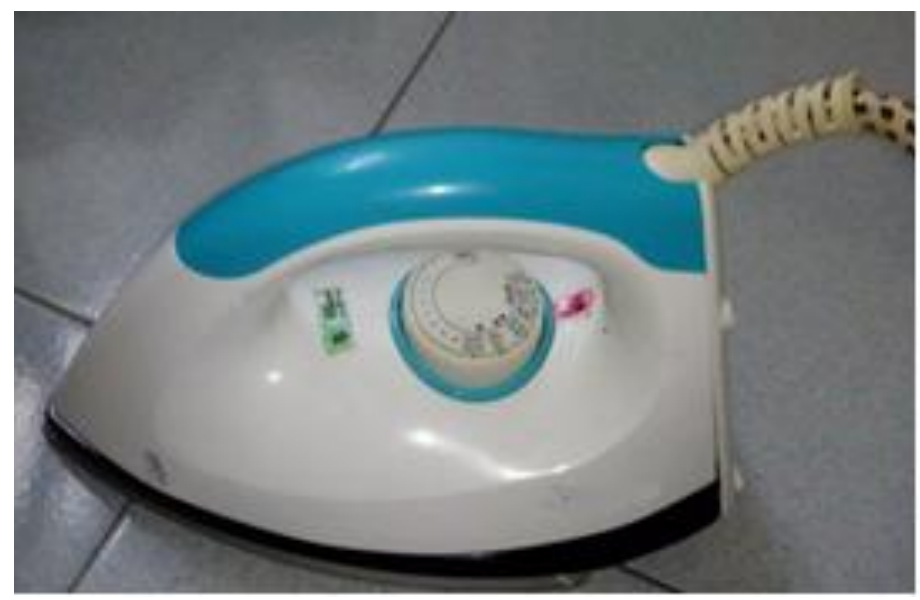

Fig. (1). Dry iron A.

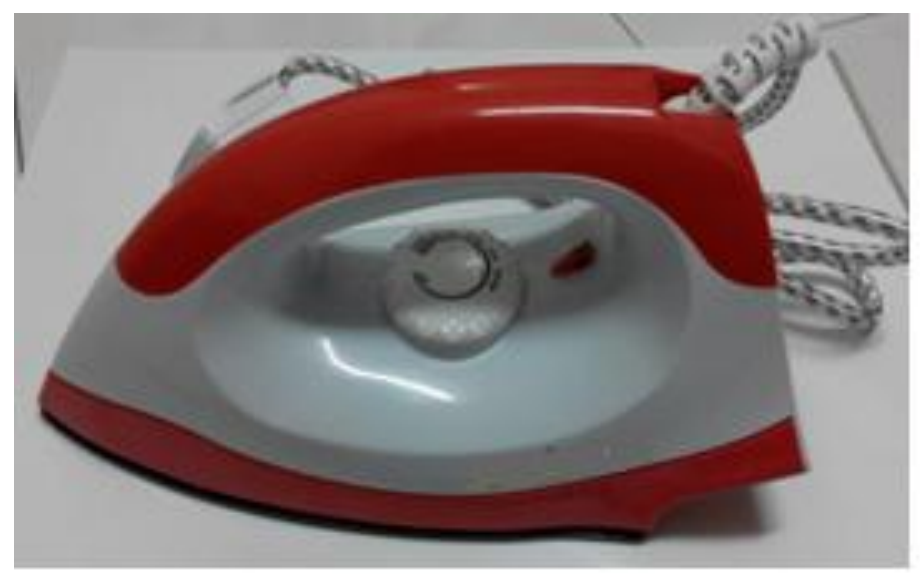

Fig. (2). Dry iron B.

\subsection{Overall Steps to Compute Design Efficiency}

The design efficiency analysis was carried out based on two factors, namely 1) consideration of the possibility to eliminate the part or to combine with other parts of the assembly, and 2) consideration of the estimated time taken to grasp, manipulate, and insert the part. The following procedure was adopted to apply the DFMA in the dry irons case.

- The existing products were identified, obtained and the detail designs of the products reproduced with the aid of CATIA.

- The products were disassembled apart and a specific identification number was assigned to each part. The part that disassembled last was assigned to the highest identification number. It is also the inner part of a product. The outer part was assigned with the lowest identification number, which is "part 1."

- Reconstruction of the products was carried out in another way round, where the parts with the highest identification number were assembled first as they were inner parts and the whole assembly ended up with part 1 (outer parts or the part that disassembled first). Then, the Boothroyd Dewhurst assembly worksheet shown in Table 1 was filled up.

- The computation of design efficiency was carried out based on the equation (1) 


$$
E_{M}=N_{M} T_{A} / T_{M} \ldots(1)
$$

where, $\mathrm{E}_{\mathrm{M}}=$ design efficiency, $\mathrm{N}_{\mathrm{M}}=$ estimation for the theoretical minimum part, and $\mathrm{T}_{\mathrm{M}}=$ Assembly time, $\mathrm{T}_{\mathrm{A}}=$ is taken as 3 , based on the average value of theoretical assembly time.

Table 1. Design for manual assembly worksheet.

\begin{tabular}{|l|l|l|l|l|l|l|l|}
\hline $\begin{array}{l}\text { Name of } \\
\text { Assembly }\end{array}$ & C1 & C2 & C3 & C4 & C5 & C6 & C7 \\
\cline { 2 - 6 } & $\begin{array}{l}\text { Total angle of } \\
\text { symmetry }(\alpha \\
+\beta), \text { deg }\left(^{\circ}\right)\end{array}$ & $\begin{array}{l}\text { Number of times } \\
\text { the operation is } \\
\text { carried out } \\
\text { consecutively }\end{array}$ & $\begin{array}{l}\text { Two-digit } \\
\text { manual } \\
\text { handling } \\
\text { code }\end{array}$ & $\begin{array}{l}\text { Manual } \\
\text { handling } \\
\text { time per } \\
\text { part (s) }\end{array}$ & $\begin{array}{l}\text { Two-digit } \\
\text { manual } \\
\text { insertion } \\
\text { code }\end{array}$ & $\begin{array}{l}\text { Manual } \\
\text { insertion } \\
\text { time per } \\
\text { part (s) }\end{array}$ & $\begin{array}{l}\text { Total } \\
\text { Operation } \\
\text { time, seconds } \\
(\mathbf{s})\end{array}$ \\
\hline 1. & & & & & $\begin{array}{l}\text { Figure for } \\
\text { estimation of } \\
\text { theoretical } \\
\text { minimum parts }\end{array}$ \\
\hline 2. & & & & & & \\
\hline $\begin{array}{l}\text { Design } \\
\text { Efficiency } \\
3 \mathrm{x} \text { NMTM }\end{array}$ & & & & & & NM \\
\hline
\end{tabular}

\subsection{Analysis of Existing Products for the Theoretical Minimum Part Count}

The first step to compute the design efficiency was to determine the theoretical part number count. There are three elements; movement, isolation, and adjustment or replacement considered while carrying out this task. The theoretical minimum part count for the product was obtained by answering the questions reflected by these three elements. The part was considered theoretically unnecessary if the answer to all three questions is "No." On the other hand, it was considered as theoretical minimum part count if either one of the criteria questions is "Yes." However, in the DFMA method, the theoretical minimum part count concerns about the number of essential part of the product without considering the cost and time affected due to the part. The main features of the Boothroyd Dewhurst method are the rules in estimating the theoretical minimum parts of the product as a guidance to fill up column 8 (C8) of Table 1. The following are the three rules considered in this study:

- Rule 1 is about the movement of the part: Does this part move relative to all other parts that are already assembled in the system?

- Rule 2 is about the isolation of part: Must this part be made of different material than other parts already assembled in the system?

- Rule 3 is about adjustment/replacement of parts: Must this part be separated from all other parts already assembled in the system?

If the answer to any of these questions is "Yes," the number " 1 " is entered in column 8 as it is an essential part and " 0 " for the non-essential part. Table 2 shows the two examples of how the theoretical minimum part count was analyzed for the dry irons. The knob ring was considered theoretically non-essential as all the answers for the rules are "NO." Meanwhile, the knob was considered theoretically essential part of the dry iron because all the answers are "YES." Thus, column C8 of knob ring and knob are filled with " 0 " and "1" respectively. Based on the analysis, there are six essential theoretical parts for both dry irons as shown in Tables $\mathbf{3}$ and $\mathbf{4}$. The outline of standard procedure as in [1] was followed in order to fill in the columns $\mathrm{C} 1$ through $\mathrm{C}$. Since the recommended time taken for manual insertion of the part was stated in the standard table that was provided in [1] which is based on theoretical values, the influence of assembly as mentioned in $[12,13]$ was ignored in this study. The analyses as in Sections 2.2 and 2.3 were repeated for the newly improved designs for internal validation and the result of the analysis is shown in Table 6.

The improvement of the dry iron was carried out by considering the following step:

- STEP 1: IF the value in column 8 (C8) LESS THEN the value in column 2 (C2), THEN it was considered as an opportunity to reduce the number of parts.

- STEP 2: Check columns 4 (C4) and 6 (C6). These figures indicate potential for assembly time reduction.

Based on product disassembly of the both dry irons, dry iron A has 24 components and dry iron B has 20 components. 
Table 2. The example of the theoretical minimum part count of dry iron.

\begin{tabular}{|c|c|c|c|l|c|l|}
\hline No & Part & $\begin{array}{l}\text { Rule 1 } \\
\text { (Movement) }\end{array}$ & $\begin{array}{l}\text { Rule 2 } \\
\text { (Isolation) }\end{array}$ & $\begin{array}{l}\text { Rule 3 } \\
\text { (Adjustment/ } \\
\text { replacement) }\end{array}$ & Theoretical Part & Justification \\
\hline 1. & Knob ring & No & No & No & $\mathrm{x}$ & $\begin{array}{l}\text { The knob ring is unnecessary because it can be combined with } \\
\text { another component }\end{array}$ \\
\hline 2. & Knob & Yes & Yes & Yes & $\sqrt{ }$ & This component operates as a rotating part so it is an essential part. \\
\hline
\end{tabular}

Table 3. Design efficiency of the dry iron A.

\begin{tabular}{|c|c|c|c|c|c|c|c|c|}
\hline \multirow[t]{2}{*}{ Name of Assembly } & C1 & C2 & C3 & C4 & C5 & C6 & C7 & \multirow{2}{*}{\begin{tabular}{|l|} 
C8 \\
Figure for \\
estimation o \\
theoretical \\
minimum \\
parts \\
\end{tabular}} \\
\hline & $\begin{array}{l}\text { Total angle of } \\
\text { symmetry }(\alpha \\
+\beta), \operatorname{deg}\left({ }^{\circ}\right)\end{array}$ & $\begin{array}{l}\text { Number of times } \\
\text { the operation is } \\
\text { carried out } \\
\text { consecutively }\end{array}$ & $\begin{array}{l}\text { Two-digit } \\
\text { manual } \\
\text { handling } \\
\text { code }\end{array}$ & \begin{tabular}{|l} 
Manual \\
handling \\
time per part \\
(s)
\end{tabular} & $\begin{array}{l}\text { Two-digit } \\
\text { manual } \\
\text { insertion } \\
\text { code }\end{array}$ & $\begin{array}{l}\text { Manual } \\
\text { insertion } \\
\text { time per } \\
\text { part (s) }\end{array}$ & \begin{tabular}{|l} 
Total \\
Operation \\
time, seconds \\
$(\mathbf{s})$ \\
$(\mathrm{C} 4+\mathrm{C} 6)$ \\
\end{tabular} & \\
\hline 1. Casing & 720 & 1 & 30 & 1.95 & 17 & 9.0 & \begin{tabular}{|l|}
10.95 \\
\end{tabular} & 1 \\
\hline 2. Knob Ring & 540 & 1 & 23 & 2.36 & 31 & 5.0 & 7.36 & 0 \\
\hline 3. Knob & 360 & 1 & 10 & 1.50 & 01 & 2.5 & 4.00 & 1 \\
\hline $\begin{array}{l}\text { 4. Signal Lamp } \\
\text { Cover }\end{array}$ & 720 & 1 & 70 & 5.10 & 02 & 2.5 & 7.60 & 1 \\
\hline 5. Handle & 720 & 1 & 30 & 1.95 & 06 & 5.5 & 5.45 & 0 \\
\hline 6. Vertical Cord Lift & 540 & 1 & 20 & 1.80 & 01 & 2.5 & 4.30 & 0 \\
\hline 7. Back Cover & 720 & 1 & 30 & 1.95 & 00 & 1.5 & 2.45 & 0 \\
\hline 8. Thermostat & 720 & 1 & 83 & 5.60 & 16 & 8.0 & 13.60 & 1 \\
\hline 9. Sole Plate & 0 & 1 & 00 & 1.13 & 00 & 1.5 & 2.63 & 1 \\
\hline 10. Sole Plate Cover & 720 & 1 & 30 & 1.95 & 13 & 6.0 & 7.95 & 1 \\
\hline 11.Sole Back Plate & 720 & 1 & 30 & 1.95 & 48 & 8.5 & 10.45 & 0 \\
\hline 12.Screw A & 360 & 5 & 11 & 1.80 & 39 & 8.0 & 49.00 & 0 \\
\hline 13.Screw B & 360 & 8 & 11 & 1.80 & 39 & 8.0 & 78.40 & 0 \\
\hline \multirow{2}{*}{\multicolumn{7}{|c|}{ Design Efficiency $=3(6) 204.14=0.0882$}} & TM & NM \\
\hline & & & & & & & 204.14 & 6 \\
\hline
\end{tabular}

Table 4. Design efficiency of the dry iron $B$.

\begin{tabular}{|c|c|c|c|c|c|c|c|c|}
\hline \multirow[t]{2}{*}{ Name of Assembly } & C1 & C2 & C3 & C4 & C5 & C6 & C7 & C8 \\
\hline & $\begin{array}{l}\text { Total angle of } \\
\text { symmetry }(\alpha \\
+\beta), \operatorname{deg}\left({ }^{\circ}\right)\end{array}$ & $\begin{array}{l}\text { Number of times } \\
\text { the operation is } \\
\text { carried out } \\
\text { consecutively }\end{array}$ & $\begin{array}{l}\text { Two-digit } \\
\text { manual } \\
\text { handling } \\
\text { code }\end{array}$ & \begin{tabular}{|l|} 
Manual \\
handling \\
time per part \\
(s)
\end{tabular} & $\begin{array}{l}\text { Two-digit } \\
\text { manual } \\
\text { insertion } \\
\text { code }\end{array}$ & $\begin{array}{l}\text { Manual } \\
\text { insertion } \\
\text { time per } \\
\text { part (s) }\end{array}$ & $\begin{array}{l}\text { Total } \\
\text { Operation } \\
\text { time, seconds } \\
\text { (s) }\end{array}$ & $\begin{array}{l}\text { Figure for } \\
\text { estimation of } \\
\text { theoretical } \\
\text { minimum } \\
\text { parts }\end{array}$ \\
\hline 1. Casing & 720 & 1 & 30 & 1.95 & 17 & 9.0 & 10.95 & 1 \\
\hline 2. Knob & 360 & 1 & 10 & 1.50 & 01 & 2.5 & 4.00 & 1 \\
\hline $\begin{array}{l}\text { 3. Signal Lamp } \\
\text { Cover }\end{array}$ & 720 & 1 & 70 & 5.10 & 02 & 2.5 & 7.60 & 1 \\
\hline 4. Handle & 720 & 1 & 30 & 1.95 & 06 & 5.5 & 5.45 & 0 \\
\hline $\begin{array}{l}\text { 5. Vertical Cord } \\
\text { Lift }\end{array}$ & 720 & 1 & 20 & 1.80 & 01 & 2.5 & 4.30 & 0 \\
\hline 6. Thermostat & 720 & 1 & 83 & 5.60 & 16 & 8.0 & 13.6 & 1 \\
\hline 7. Sole Plate & 0 & 1 & 00 & 1.13 & 00 & 1.5 & 2.63 & 1 \\
\hline
\end{tabular}




\begin{tabular}{|c|c|c|c|c|c|c|c|c|}
\hline \multirow[t]{2}{*}{ Name of Assembly } & C1 & $\mathrm{C2}$ & C3 & $\mathrm{C4}$ & C5 & C6 & C7 & C8 \\
\hline & $\begin{array}{l}\text { Total angle of } \\
\text { symmetry }(\alpha \\
+\beta), \operatorname{deg}\left({ }^{\circ}\right)\end{array}$ & $\begin{array}{l}\text { Number of times } \\
\text { the operation is } \\
\text { carried out } \\
\text { consecutively }\end{array}$ & $\begin{array}{l}\text { Two-digit } \\
\text { manual } \\
\text { handling } \\
\text { code }\end{array}$ & $\begin{array}{l}\text { Manual } \\
\text { handling } \\
\text { time per part } \\
\text { (s) }\end{array}$ & $\begin{array}{l}\text { Two-digit } \\
\text { manual } \\
\text { insertion } \\
\text { code }\end{array}$ & $\begin{array}{l}\text { Manual } \\
\text { insertion } \\
\text { time per } \\
\text { part (s) }\end{array}$ & $\begin{array}{l}\text { Total } \\
\text { Operation } \\
\text { time, seconds } \\
\text { (s) }\end{array}$ & $\begin{array}{l}\text { Figure for } \\
\text { estimation of } \\
\text { theoretical } \\
\text { minimum } \\
\text { parts }\end{array}$ \\
\hline 8. Sole Plate Cover & 720 & 1 & 30 & 1.95 & 13 & 6.0 & 7.95 & 1 \\
\hline 9. Screw A & 360 & 5 & 11 & 1.80 & 39 & 8.0 & 49.0 & 0 \\
\hline 10. Screw B & 360 & 7 & 11 & 1.80 & 39 & 8.0 & 68.6 & 0 \\
\hline \multirow{2}{*}{\multicolumn{7}{|c|}{ Design Efficiency $=3(6) 174.08=0.1034(10.34 \%)$}} & TM & NM \\
\hline & & & & & & & 174.08 & 6 \\
\hline
\end{tabular}

\section{RESULTS AND DISCUSSION}

\subsection{Design Efficiency of the Dry Irons}

The design efficiency of two different brands of the product was analyzed using Boothroyd Dewhurst DFMA methods for manual assembly. The design efficiency of the product was calculated based on equation (1). Tables $\mathbf{3}$ and 4 show the analysis result of the dry irons A and B. The total assembly time of dry iron A was 204.14s with 6 theoretical minimum part count that leads to the design efficiency of $8.82 \%$. The total assembly time of dry iron A was $174.08 \mathrm{~s}$ with 6 theoretical minimum part count leading to the design efficiency of $10.34 \%$. Based on this result, there are 7 components of the dry iron A (knob ring, handle, vertical cord lift, back cover, sole back plate, screw A and B) and 4 components of the dry iron B (handle, vertical cord lift, screw A, and B) can be eliminated due to the value in column 8 being smaller than in column 2 .

\subsection{Design Improvement of Dry Iron B}

The modification for the design improvement was carried out on dry iron B based on its DFMA analysis. In general, some of the components were suggested to be eliminated and some modifications have been implemented in the components. The handle, vertical cord lift and a few screws were eliminated while the casing of the handle and vertical cord lift were combined into one component. Instead of using several screws and locating pin, the snap fit principle was employed to replace the existing method. Another modification was adding a slide button on the sole plate cover for ease of releasing or attaching with the casing. This method requires less time for the installation and the screws is unnecessary as shown in figures of Table $\mathbf{5}$.

Table 5 shows the modification suggested for the dry iron design. The original design and new design are shown and explained in the table. The reason for modification of the design and the differences between them are also explained. It was obvious that the new design fulfilled the objectives of the project in term of reducing assembly time and directly improved the percentage of design efficiency of the new design.

Table 5. Suggestion of design modifications for dry iron $B$.

\begin{tabular}{|l|l|l|}
\hline \multicolumn{1}{|c|}{ Modification } & \multicolumn{1}{|c|}{ Figure } & \multicolumn{1}{c|}{ Justifications } \\
\hline $\begin{array}{l}\text { Modify the casing by adding a } \\
\text { hanger and tow snaps }\end{array}$ & $\begin{array}{l}\text { The two screws can be eliminated as it can be replaced with a tow-snap. The } \\
\text { hanger can be assembled to the sole plate cover. }\end{array}$ \\
\hline
\end{tabular}




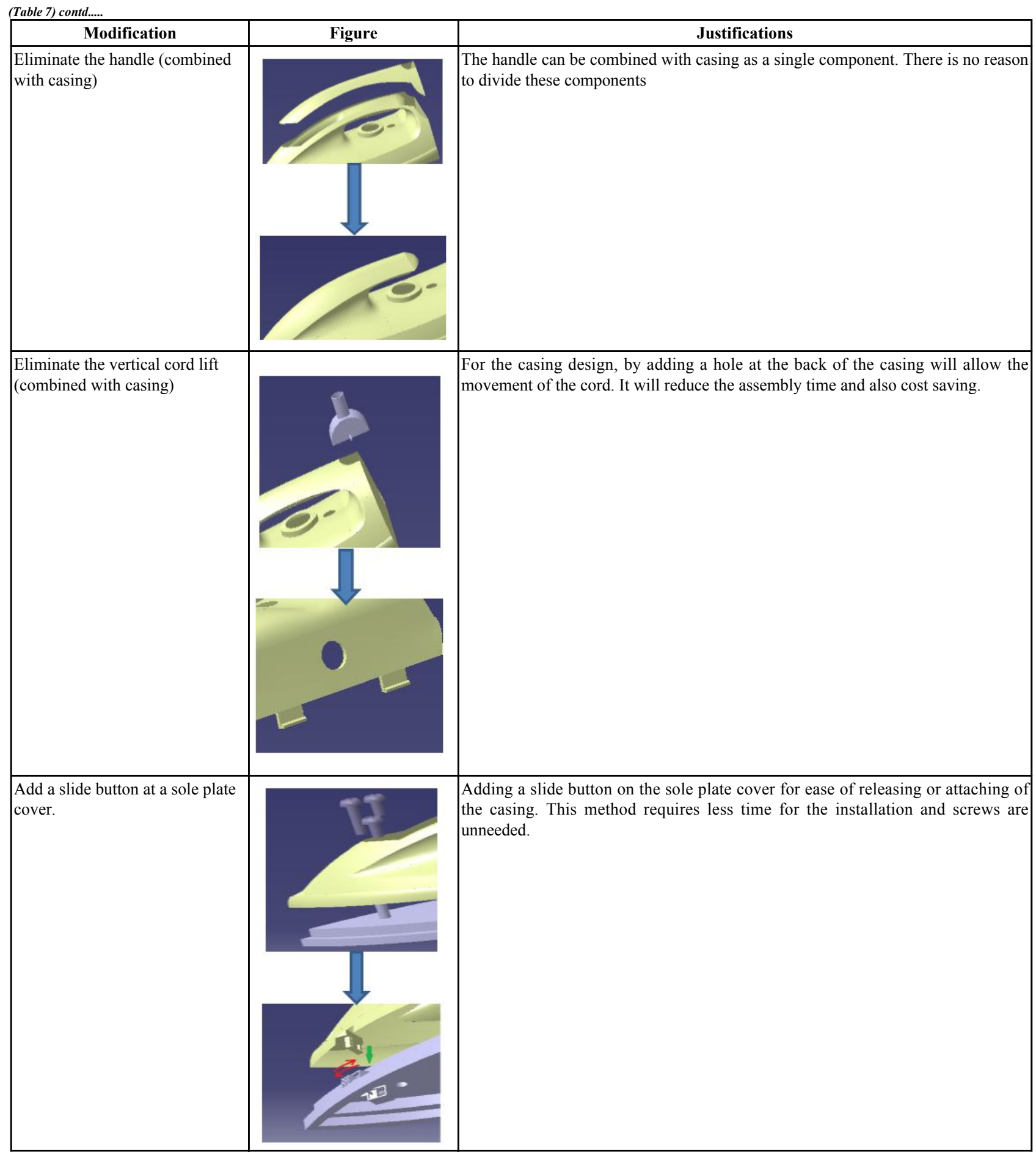


(Table $\square$ ) contd......

\begin{tabular}{|c|c|c|}
\hline Modification & Figure & Justifications \\
\hline $\begin{array}{l}\text { Eliminate two threads and two } \\
\text { screws }\end{array}$ & & $\begin{array}{l}\text { These threads can be replaced by two snap holes, which are matched to the casing } \\
\text { during installation. This design does not need the use a screwdriver during } \\
\text { installation and it helps to save assembly time and indirectly increased the design } \\
\text { efficiency of the product. }\end{array}$ \\
\hline
\end{tabular}

\subsection{Design Efficiency of Dry Iron B After Modification}

The analysis found that the design efficiency of the new dry iron B is $18.08 \%$ and the total assembly time is $132.73 \mathrm{~s}$ with 8 theoretical minimum parts count as shown in Table 4.

Table 6. Analytical results of the new dry iron.

\begin{tabular}{|c|c|c|c|}
\hline Item & Quantity & $\begin{array}{c}\text { Theoretical Minimum } \\
\text { Part Count }\end{array}$ & Assembly Time (seconds) \\
\hline 1. Casing & 1 & 1 & 7.45 \\
\hline 2. Knob & 1 & 1 & 4.00 \\
\hline 3. Signal Lamp Cover & 1 & 1 & 7.60 \\
\hline 4. Spring & 1 & 1 & 6.35 \\
\hline 5. Slide Button & 1 & 1 & 4.75 \\
\hline 6. Thermostat & 1 & 1 & 13.60 \\
\hline 7. Sole Plate & 1 & 1 & 2.63 \\
\hline 8. Sole Plate Cover & 1 & 1 & 7.95 \\
\hline 9. Screw A & 3 & 0 & 29.40 \\
\hline 10. Screw B & 5 & 0 & 49.00 \\
\hline & & NM & TM \\
\hline TOTALS & 16 & 8 & 132.73 \\
\hline \multicolumn{2}{|c|}{ DESIGN EFFICIENCY } & \multicolumn{2}{|c|}{0.1808} \\
\hline
\end{tabular}

Table 7. Comparison between existing design and new design.

\begin{tabular}{|l|c|c|}
\hline \multicolumn{1}{|c|}{ Item } & \multicolumn{2}{c|}{ Existing Design } \\
\cline { 2 - 4 } & Dry iron A & Dry iron B Design \\
(Dry Iron B)
\end{tabular}

The percentage of design efficiency of existing design for dry iron A was $8.82 \%$ and dry iron B was $10.34 \%$. The DFMA analysis result showed the dry iron B is much superior to dry iron A in terms of its assembly operation and its design efficiency. Therefore, design modifications for improvement were proposed for dry iron $\mathrm{B}$

As shown in Table 7, dry iron B contains 10 different parts with a total of 20 components. After modification, the new design of dry iron B contains 10 different of parts with a total of 16 components. It was clearly shown that the total number of components for the new design is less by 4 components compared to existing design of dry iron B. Some of these components were combined as a single component and some unnecessary components/features were eliminated. The DFMA analysis results shown the percentage of design efficiency of new conceptual design is $18.08 \%$. Due to this 
reason, the new dry iron has a higher percentage of design efficiency compared to both existing dry iron.

\section{CONCLUSION}

The number of components and assembly method are the important factors affecting the design efficiency of a product. In this research, the number of total components of the new dry iron was reduced from 20 components to 16 with the application of the DFMA analysis. The total assembly operation time reduced from $174.08 \mathrm{~s}$ to $132.73 \mathrm{~s}$. It obviously shortens the assembly time by about $41.35 \mathrm{~s}$ or $23.75 \%$. The reduction of assembly time is contributed by the elimination and combination of certain components based on DFMA analysis result. This reduction in the component will ultimately improve the eco-friendliness of the product.

\section{CONFLICT OF INTEREST}

The authors confirm that this article content has no conflict of interest.

\section{ACKNOWLEDGEMENTS}

The authors gratefully acknowledged the financial support from Universiti Teknikal Malaysia Melaka (UTeM) and The Ministry of Higher Education, Malaysia (MOHE).

\section{REFERENCES}

[1] G. Boothroyd, P. Dewhurst, and W. Knight, Product Design for Manufacture and Assembly., $2^{\text {nd }}$ ed Marcel Dekker: New York, 2002.

[2] J.P. Kovalchuk, O. Canciglieri Júnior, and A. Batocchio, "Concurrent Engineering application on the development of parts for the White Goods industry in Brazil-A case study", In: Proceedings of the 2006 Conference on Leading the Web in Concurrent Engineering: Next Generation Concurrent Engineering, 2006, pp. 805-817.

[3] N. Mendoza, H. Ahuett, and A. Molina, "Case Studies in the Integration of QFD, VE and DFMA during the Product Design Stage", In: Proceedings of the $9^{\text {th }}$ International Conference on Concurrent Engineering, Espoo, Finland, 2003. Available from: http://www.ico.org

[4] W.N. Prakash, V.G. Sridhar, and K. Annamalai, "“New product development by DFMA and rapid prototyping”, ARPN", J. Eng. Appl. Sci. (Asian Res. Publ. Netw.), vol. 9, no. 3, pp. 274-279, 2014.

[5] C. Estorilio, and M.C. Simião, "Cost reduction of a diesel engine using the DFMA method", Prod., Manag. Dev., vol. 4, no. 2, pp. 95-103, 2006.

[6] S. Sula, and N. Bâlc, "Redesign a metering pump using DFMA techniques: A case study", In: The $11^{\text {th }}$ International MTEM Conference, Romania, 17-19 October 2013.

[7] "Mustofa, "Redesign of pneumatic piston using design for manufacture and assembly (DFMA) technique", J. Mech., vol. 1, no. 1, pp. 60-66, 2010 .

[8] J. Fiskel, and K. Wapman, "How to design for environment and minimize life cycle cost", In: IEEE International Symposium on Electronics \& the Environment, San Francisco, CA, 1994.

[9] P. Suresh, S. Ramabalan, and U. Natarajan, "Integration of DFE and DFMA for the sustainable development of an automotive component", Int. J. Sustainable Eng., vol. 9, pp. 1-12, 2016.

[10] R. Gheorghe, and K. Ishii, "Eco-design value alignment: Keys to success", In: ASME 2007 International Mechanical Engineering Congress and Exposition, 2007, pp. 267-277.

[11] J.C. Braga, "M.L.A.C de Castro and M.T.D.M Colessanti, "Method of decision-making applied to the analysis of the environmental performance of a product: The case study of a Spirit fan", Strat. Des. Res. J., vol. 6, no. 2, pp. 46-57, 2014. [http://dx.doi.org/10.4013/sdrj.2013.62.01]

[12] M.R. Bahubalendruni, B.B. Biswal, M. Kumar, and R. Nayak, "Influence of assembly predicate consideration on optimal assembly sequence generation", Assem. Autom., vol. •, pp. 309-316, 2015. [http://dx.doi.org/10.1108/AA-03-2015-022]

[13] M.R. Bahubalendruni, and B.B. Biswal, "“A review on assembly sequence generation and its automation”, Proceeding of the Institution of Mechanical Engineer, Part C", J. Mech. Eng. Sci., vol. 230, no. 3, pp. 824-838, 2015.

(C) Sudin et al.; Licensee Bentham Open

This is an open access article licensed under the terms of the Creative Commons Attribution-Non-Commercial 4.0 International Public License (CC BY-NC 4.0) (https://creativecommons.org/licenses/by-nc/4.0/legalcode), which permits unrestricted, non-commercial use, distribution and reproduction in any medium, provided the work is properly cited. 